\title{
Redescription of Sarsia japonica (Nagao) (Hydrozoa: Corynidae) from Hokkaido, Japan
}

AUTHOR(S):

Kubota, Shin; Takashima, Yoshikazu

\section{CITATION:}

Kubota, Shin ... [et al]. Redescription of Sarsia japonica (Nagao) (Hydrozoa : Corynidae) from Hokkaido, Japan. PUBLICATIONS OF THE SETO MARINE BIOLOGICAL LABORATORY 1992, 35(6): 371-381

\section{ISSUE DATE:}

1992-11-30

URL:

http://hdl.handle.net/2433/176209

RIGHT: 


\title{
Redescription of Sarsia japonica (Nagao) (Hydrozoa: Corynidae) from Hokkaido, Japan
}

\author{
Shin Kubota \\ Seto Marine Biological Laboratory, Kyoto University, Shirahama, \\ Wakayama 649-22, Japan \\ and \\ Yoshikazu Takashima \\ Zoological Institute, Faculty of Science, Hokkaido University, \\ Sapporo 060, Japan
}

With Text-figures 1-14 and Tables 1-3

\begin{abstract}
Sarsia japonica (Nagao) is redescribed and illustrated, based on 1 female and 6 male colonies collected from Muroran (a new locality) and Akkeshi (the type locality), Hokkaido, Japan. Previousily undescribed character states of both the hydroid and the laboratory-reared medusa are noted and the substrata occupied by this species and its geographical distribution are summarized. Sarsia japonica is judged to be a distinct species, and the characteristics that distinguish its hydroid and medusa from those of its closest congener, $S$. producta (Wright), are pointed out.
\end{abstract}

Sarsia japonica was originally described by Nagao (1962) as Stauridiosarsia japonica based on hydroid colonies collected at Akkeshi, Hokkaido, Japan, and on female medusae released by them in the laboratory. In the second reported occurrence of this species, Arai and Brinckmann-Voss (1980) found the medusa in British Columbia, Canada, and they transferred the species to Sarsia Lesson, 1843. Hirohito (1988), His Majesty the Emperor Showa of Japan, also treated the present species as Sarsia japonica (Nagao). Brinckmann-Voss (1989) recognized S. japonica as a distinct member of the "eximia"-group of species within Sarsia after her comparative work on the life cycles of S. eximia (Allman, 1859), S. cliffordi Brinckmann-Voss, 1989, and S. producta (Wright, 1858). Recently, Petersen (1990) separated S. eximia from the other members of the "eximia"'-group and assigned them respectively to two species groups in another genus Coryne; S. cliffordi was not treated. The two species groups of Cory$n e$ were redefined based on both the hydroid and the medusa, adopting a cladistic analysis. However, some characteristics of the present species and another species of the "eximia"-group do not precisely accord with Petersen's new definition of Cory$n e$, as described below. Therefore, the earlier generic assignment of the present species and the others in the "eximia"-group is maintained here.

The present paper is the third report on Sarsia japonica. It describes previously unreported character states of the hydroid and mature medusa as well as the morphology of the gametes, with illustrations of the nematocysts.

Publ. Seto Mar. Biol. Lab., 35(6), 371-381, 1992. (Article 17) 


\section{Material and Methods}

Four colonies, 1 female and 3 male, were collected from the intertidal region of a rocky shore facing the Pacific Ocean at Denshinhama in Muroran, Hokkaido, northern Japan, in late April and the middle of May, 1988 and 1990. These colonies were mainly used for the redescription, being examined soon after collection and reexamined afterwards in the course of the study of the life cycle. The hydroids were cultured in the laboratory, kept on natural substrata or transplanted into polystyrene vessels, $60 \mathrm{~mm}$ wide and $30 \mathrm{~mm}$ deep or $80 \mathrm{~mm}$ wide and $40 \mathrm{~mm}$ deep. The culture medium was filtered seawater brought from Oshoro Bay, Hokkaido, facing the Sea of Japan, or the Itanki fishing port in Muroran, Hokkaido, facing the Pacific Ocean, or artificial seawater (Jamarin U). The hydroids and their medusae were kept at $6^{\circ} \mathrm{C}$ (a small number of material was at $12^{\circ} \mathrm{C}$ ) under alternating 12-hour periods of light and dark, and fed every day with newly hatched Artemia nauplii. The medium was changed at least every $2-3$ days. The medusae were reared individually.

Three additional male colonies from the type locality were reexamined by the same methods. They were collected from the subtidal region at Nakanose in Akkeshi Bay, Hokkaido, Japan, ca. $5 \mathrm{~m}$ in depth, by dredging in July, 1983 and 1990.

Measurements were taken of living or $\mathrm{MgCl}_{2}$-anaesthetized specimens collected from Muroran, using a binocular microscope and a phase-contrast microscope. All measurements are shown as mean $\pm S D$ and range. The number of colonies examined is also shown in brackets if the number is below four. The figures were drawn with the aid of drawing tubes attached to the microscopes.

\section{Sarsia japonica (Nagao, 1962)}

(Figs. 1-14)

Stauridiosarsia japonica Nagao, 1962, pp. 176-181, Figs. 1-5.

Sarsia japonica: Arai \& Brinckmann-Voss, 1980, p. 21, Fig. 10.

Hydroid. The hydranth (Figs. 1,2) is clavate, with up to four whorls of capitate tentacles occupying nearly the entire distal half of the hydranth. The distal whorl of capitate tentacles consists of four or five (sometimes six) tentacles, all of nearly the same length. Most of the other capitate tentacles are also of the same length to these. All tentacles taper distally, but the distal portion retains more than half the diameter of the proximal portion. Medusa buds in up to four clusters encircle the middle of the hydranth just below or among the capitate tentacles in the lowest whorl. Each medusa bud is produced on a short stalk without lateral branches. Up to four medusa buds are congregated in each cluster, and a maximum of 14 medusa buds per hydranth is found at a time. A single whorl of filiform tentacles or spinous processes, 2-5 per hydranth, is often found lower than the medusa buds on regenerated hydranths or zooids reared in the laboratory. The filiform tentacles are up to 1.4 $\mathrm{mm}$ in length, sometimes being longer than the capitate tentacles. The hydrorhiza consists of an irregular network of reticulated creeping stolons, giving off erect hydrocauli which very rarely branch once or twice. When stolons belonging to the same colony meet, they fuse in many cases. The periderm of the hydrorhiza and hydrocauli is smooth, without annulations. Just after collection the hydranth is orange or pink and well-developed medusa buds have four black ocelli.

The measurements (in $\mathrm{mm}$ ), ratios, and meristic characters of the hydroid are as follows. Length $\mathrm{X}$ maximum width of hydranth, $2.0 \pm 0.4(1.3-2.7) \mathrm{N}=18 \mathrm{X}$ 


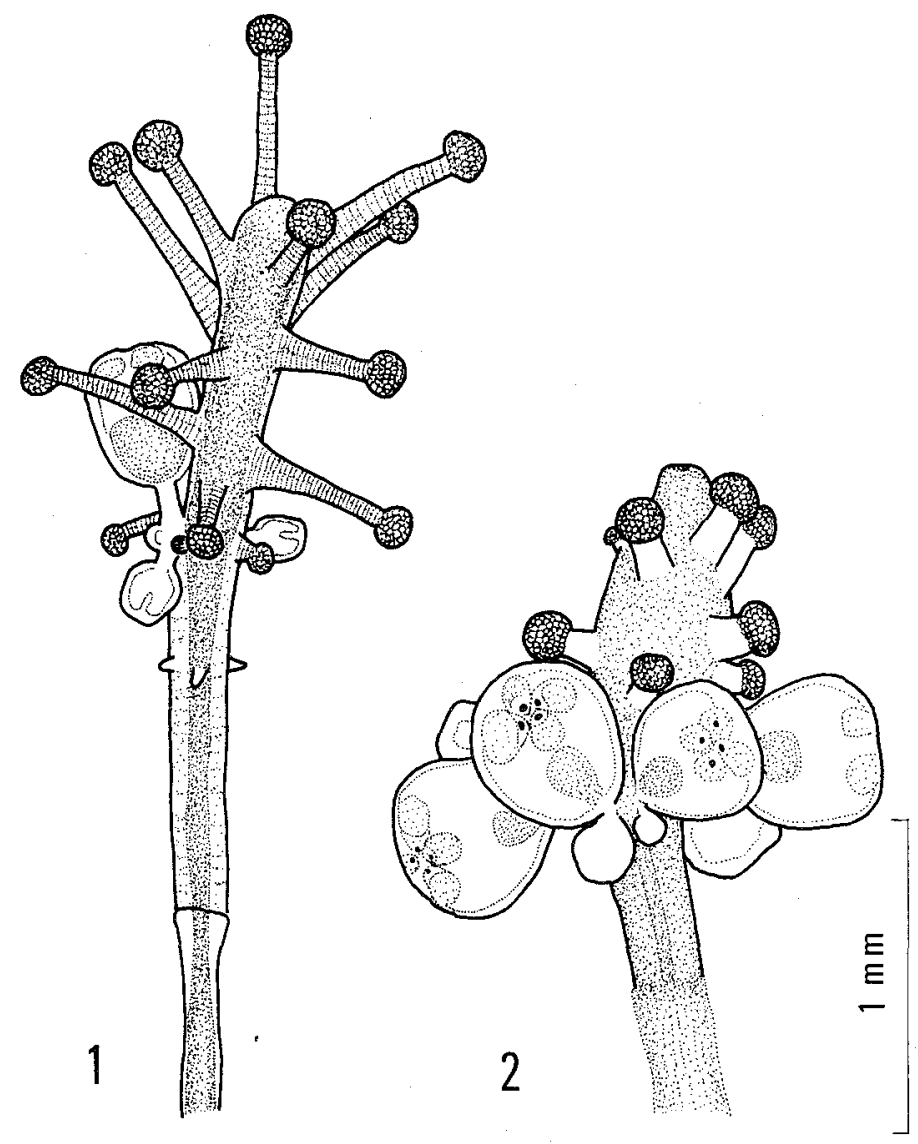

Figs. 1, 2. Morphology of hydroid of Sarsia japonica from Muroran, Hokkaido, Japan, drawn from life. 1: Laboratory-reared male zooid (not a regenerated hydranth) with spinous processes. 2: Female hydranth with 15 capitate tentacles and 14 medusa buds, just after collection, slightly contracted. Note that filiform tentacles are absent.

$0.27 \pm 0.05(0.20-0.44) \mathrm{N}=15$. Ratio of tentacle-bearing length of hydranth to total length of hydranth, $0.6 \pm 0.1(0.5-0.6) \mathrm{N}=7$ [3]. Maximum width of hydrocaulus, $0.18 \pm 0.05(0.13-0.25) \mathrm{N}=6[3]$. Number of capitate tentacles per hydranth, $18 \pm 3(12-24) \mathrm{N}=18$. Maximum length of capitate tentacles per zooid, $0.50 \pm$ $0.09(0.31-0.63) \mathrm{N}=14$. Ratio of maximum length of capitate tentacles to maximum width of hydranth, $1.9 \pm 0.3(1.2-2.2) \mathrm{N}=11$. Maximum height of three colonies: $9.9,4.8$, and $6.0 \mathrm{~mm}$.

1 day old medusa. The medusa possesses four long tentacles bearing many nematocyst clusters, a black ocellus on the abaxial side of each tentacular bulb, many exumbrellar nematocysts in eight adradial rows, interradial exumbrellar furrows, four radial canals, and an umbilical canal (Fig. 3). In some rows, the exumbrellar nematocysts are arranged in two obscure lines. The terminal nematocyst cluster on each tenta- 


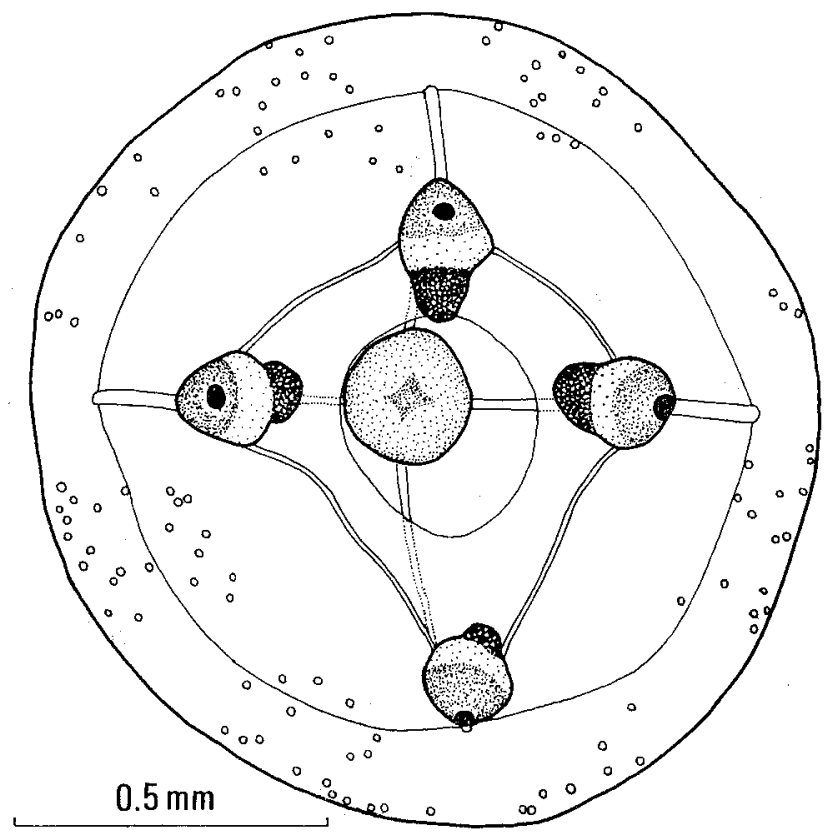

Fig. 3. Oral view of 1-day-old female medusa of Sarsia japonica from Muroran, Hokkaido, Japan, drawn from life, slightly compressed and tentalces not drawn.

cle is the largest. The length of the tubular manubrium is about half the umbrellar height. The radial canal is wider than the ring canal. Gonads are not yet found on the manubrium. The measurements and meristic characters of the medusa are as follows: dimensions of umbrella and tentacular bulbs and thickness of apical jelly are shown in Table 1; length of manubrium, $0.59 \pm 0.13 \mathrm{~mm}(0.23-0.76 \mathrm{~mm})$, $\mathrm{N}=32$; number of exumbrellar nematocysts per medusa, $213 \pm 27$ (159-248), $\mathrm{N}=$

Table 1. Dimensions of umbrella and tentacular bulbs and thickness of apical jelly of 1-day-old medusae and just matured medusae of Sarsia japonica from Muroran, Hokkaido, Japan, in $\mathrm{mm}$. Dimensions are mean $\pm \mathrm{SD}$, range, number of samples, and the number of colonies examined if it is below 4 .

\begin{tabular}{|c|c|c|c|c|c|}
\hline & \multicolumn{2}{|c|}{ Umbrella } & \multirow{2}{*}{$\begin{array}{l}\text { Thickness } \\
\text { of jelly at } \\
\text { umbrellar } \\
\text { apex }\end{array}$} & \multicolumn{2}{|c|}{ Tentacular bulb } \\
\hline & Diameter & Height & & Diameter & Height \\
\hline $\begin{array}{l}\text { Newly } \\
\text { liberated } \\
\text { medusa }\end{array}$ & $\begin{array}{l}1.3 \pm 0.2 \\
(0.94-1.7) \\
N=41\end{array}$ & $\begin{array}{c}1.3 \pm 0.2 \\
(0.88-1.9) \\
N=41\end{array}$ & $\begin{array}{l}0.14 \pm 0.04 \\
(0.08-0.19) \\
N=41\end{array}$ & $\begin{array}{c}0.15 \pm 0.02 \\
(0.10-0.20) \\
N=29[3]\end{array}$ & $\begin{array}{c}0.16 \pm 0.03 \\
(0.10-0.23) \\
N=33[3]\end{array}$ \\
\hline $\begin{array}{l}\text { Male medusa } \\
\text { 14-28 days old }\end{array}$ & $\begin{array}{l}2.8 \pm 0.2 \\
(2.6-3.2) \\
\mathrm{N}=7[3]\end{array}$ & $\begin{array}{l}3.2 \pm 0.2 \\
(2.9-3.5) \\
\mathrm{N}=7[3]\end{array}$ & $\begin{array}{c}0.77 \pm 0.10 \\
(0.69-0.94) \\
N=7[3]\end{array}$ & $\begin{array}{c}0.27 \pm 0.03 \\
(0.23-0.33) \\
N=7[3]\end{array}$ & $\begin{array}{c}0.26 \pm 0.02 \\
(0.23-0.30) \\
N=7[3]\end{array}$ \\
\hline $\begin{array}{l}\text { Female medusa } \\
10-23 \text { days old }\end{array}$ & $\begin{array}{l}3.2 \pm 0.3 \\
(3.0-3.9) \\
\mathrm{N}=9[1]\end{array}$ & $\begin{array}{l}3.9 \pm 0.4 \\
(3.5-4.6) \\
\mathrm{N}=9[1]\end{array}$ & $\begin{array}{l}1.2 \pm 0.1 \\
(1.1-1.5) \\
\mathrm{N}=9[1]\end{array}$ & - & 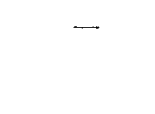 \\
\hline
\end{tabular}

- : not measured. 
13 [1]; number of exumbrellar nematocysts in each row, 26-46, $N=6$ from 5 medusae [1]; number of nematocyst clusters per tentacle, 41-43, $\mathrm{N}=3$ from 3 medusae [1].

Development of medusa. Marked morphological changes of the medusae including a thickening of the apical jelly and the appearance of gonads on most of the manubrium took place on and after the 7th day after release from the hydroid. An apical knob also appeared on the stomach in some individuals. Gonad maturation took place within 2-4 weeks thereafter (Fig. 4). Gonad maturation and spawning were repeated many times over the life span of the medusae, but no multiplication of the gonads was observed. Male medusae survived at most 147 days and female medusae 160 days ac $6^{\circ} \mathrm{C}$. The umbrella continuously increased in size after maturation (Fig. 4). Medusa bud formation on medusae was never observed.

Mature medusa. The umbrella is higher than wide and bell-shaped (Figs. 5, 6). The tubular manubrium usually hangs within the subumbrellar cavity, though it sometimes reaches the velar opening and occasionally protrudes from it for a short distance (Fig. 6). The cylindrical or fusiform gonads surround the manubrium except for the basal portion (Fig. 7) and the distal portion around the circular mouth. The exumbrellar nematocysts are present, but are often reduced in number with age. A small, conical, apical knob is sometimes present (Fig. 7). The tip of this knob is variable in shape, being sharply pointed (Fig. 5) or dull (Figs. 6, 7). The abaxial ocellus on each tentacular bulb is black or red. There are four equally developed tentacles that are several times longer than the umbrellar height. Each tentacle is inserted nearly the central part of the tentacular bulb. The endodermal cham-

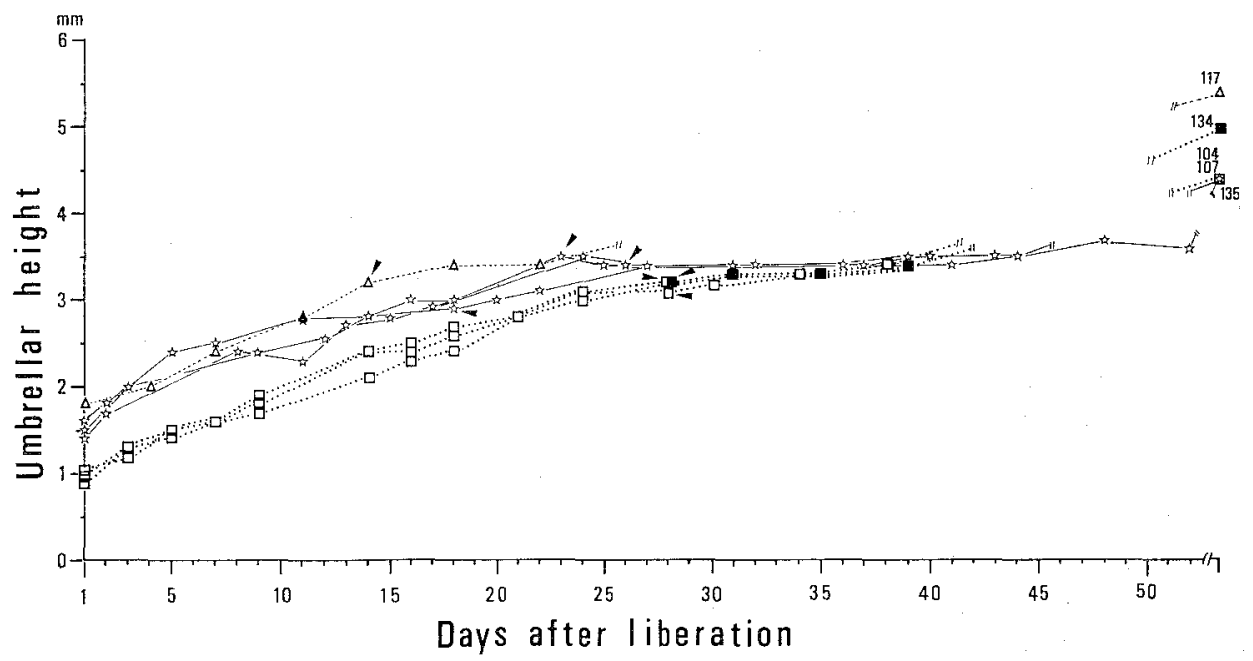

Fig. 4. Development of seven male medusae originated from three colonies (represented by triangles, stars and squares) of Sarsia japonica from Muroran, Hokkaido, Japan. Arrowheads indicate time of first maturation of gonads. Closed symbols indicate that the manubrium reaches the velar opening or protrudes from it. Numbers are ages of old medusae, in days after liberation from hydroids. 

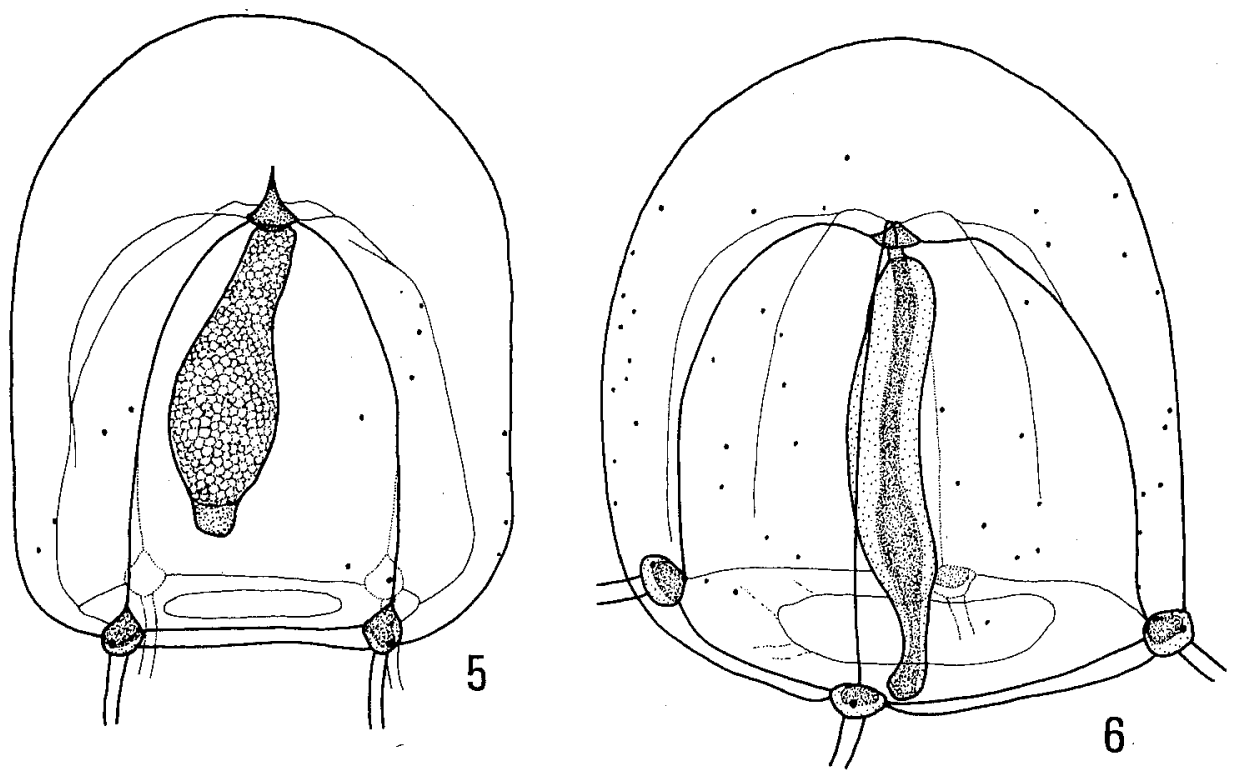

Figs. 5, 6. Two mature medusae of Sarsia japonica, drawn from life, tentacles not drawn. 5: 48-day-old female medusa from Muroran, Hokkaido, Japan, $5.2 \mathrm{~mm}$ in height. 6: 92-day-old male medusa from Akkeshi, Hokkaido, Japan, 4.2 $\mathrm{mm}$ in height.

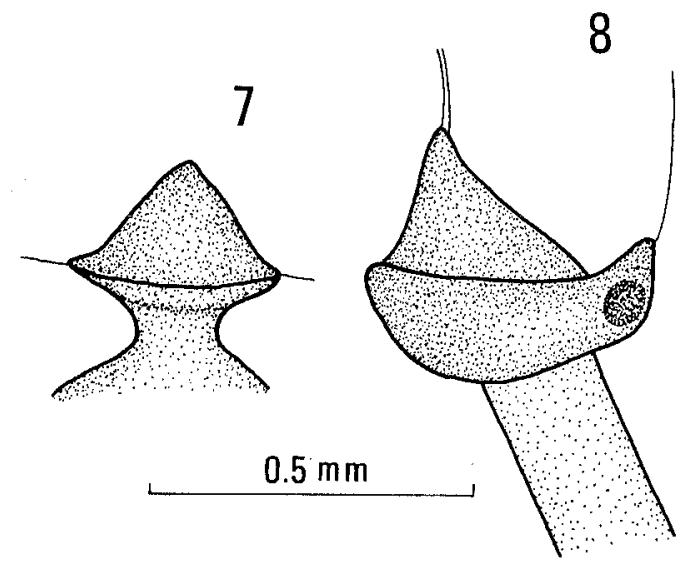

Figs. 7, 8. Body portions of female medusa of Sarsia japonica form Muroran, Hokkaido, Japan. 7: Apical knob and narrow, proximal portion of manubrium, drawn from life. 8: Tentacular bulb in side view, drawn from a preserved specimen.

ber of the tentacular bulb is triangular in side view (Fig. 8). The four radial canals extend along the subumbrellar surface for their whole length, and they are not separated from it near the tentacular bulb. Each radial canal enters the adaxial side of the endodermal chamber of the tentacular bulbs. Table 1 shows the measurements of just matured medusae of both sexes. The longest manubrium measured $3.3 \mathrm{~mm}$ in length, and the apical jelly $2.2 \mathrm{~mm}$ in thickness. The male medusae attained 5.4 $\mathrm{mm}$ in umbrellar height (Fig. 4) and the female medusae $5.9 \mathrm{~mm}$. 
Table 2. Distribution of nematocysts of hydroids and medusae of Sarsia japonica from Muroran, Hokkaido, Japan. The dimensions are length $\mathrm{x}$ maximum width of undischarged capsules, in $\mu \mathrm{m}$. Dimensions are mean $\pm \mathrm{SD}$, range, number of samples, and the number of colonies examined.

\begin{tabular}{|c|c|c|c|}
\hline & Hydroid & Newly liberated medusa & Mature medusa \\
\hline \multicolumn{4}{|l|}{ Stenoteles } \\
\hline Large type & $\begin{array}{l}30.3 \pm 1.9 \times 19.9 \pm 1.5 \\
(25.6-33.6)(18.0-23.2) \\
N=50,6 \text { zooids [2] } \\
\text { on tentacles }\end{array}$ & Absent & Absent \\
\hline \multirow[t]{2}{*}{ Small type } & $\begin{array}{l}15.5 \pm 1.1 \times 9.8 \pm 0.8 \\
(12.8-16.8)(8.8-12.0) \\
N=52,6 \text { zooids }[2] \\
\text { on tentacles }\end{array}$ & $\begin{array}{l}14.6 \pm 0.9 \times 10.2 \pm 0.7 \\
(12.8-16.0) \quad(9.6-11.6) \\
\mathrm{N}=31,4 \text { medusae [2] } \\
\text { on tentacles }\end{array}$ & $\begin{array}{l}16.0 \pm 1.0 \times 11.0 \pm 0.8 \\
(14.4-17.6) \quad(9.6-12.8) \\
\mathrm{N}=25,4 \text { medusae }[2] \\
\text { on tentacles }\end{array}$ \\
\hline & & $\begin{array}{l}11.7 \pm 0.8 \times 8.2 \pm 0.7 \\
(10.4-13.6)(7.2-9.6) \\
\mathrm{N}=19,2 \text { medusae }[1] \\
\text { on manubrium }\end{array}$ & $\begin{array}{l}13.4 \pm 3.1 \times 9.3 \pm 2.4 \\
(8.0-20.0) \quad(4.8-14.4) \\
\mathrm{N}=15,1 \text { medusa [1] } \\
\text { on manubrium }\end{array}$ \\
\hline Desmonemes & Absent & $\begin{array}{l}10.0 \pm 0.63 \times 5.1 \pm 0.4 \\
(8.8-11.2) \quad(4.0-5.6) \\
\mathrm{N}=32,4 \text { medusae }[2] \\
\text { on tentacles }\end{array}$ & $\begin{array}{l}10.9 \pm 0.8 \times 5.0 \pm 0.4 \\
(8.8-12.2) \quad(4.0-5.6) \\
\mathrm{N}=28,4 \text { medusae }[2] \\
\text { on tentacles }\end{array}$ \\
\hline $\begin{array}{l}\text { Microbasic } \\
\text { mastigophores }\end{array}$ & Absent & $\begin{array}{l}16.6 \pm 0.5 \times 13.8 \pm 0.4 \\
(16.0-17.6)(13.2-14.4) \\
N=20,3 \text { medusae [2] } \\
\text { on exumbrella }\end{array}$ & (on exumbrella) \\
\hline
\end{tabular}

- : not measured.

Nematocysts. The distribution and size of nematocysts in the three developmental stages described above are shown in Table 2. The hydroid possesses two types of stenoteles (Figs. 9, 10) on the tentacles, hydrocaulus, and hydrorhiza. The newly liberated, mature, and spent medusae have two more kinds of nematocysts, microbasic mastigophores (Figs. 11, 12) on the exumbrella and desmonemes (Fig. 13) on the tentacles, while they have only the small type of stenoteles (Fig. 14).

Gametes. The unfertilized egg with a germinal vesicle is $105 \pm 14 \mu \mathrm{m}$ in diameter within one day after discharge $(\mathrm{N}=30$, examined in three medusae originated from one colony). The number of unfertilized eggs spawned at one time was examined up to three times per individual in five specimens from one colony, and this number varied from 10 to $146(\mathrm{~N}=10)$. The head of the spermatozoon is pointed and curved as in Hydrocoryne miurensis Stechow, 1907 (see Kubota 1988).

Remarks. The general morphology of the present specimens from a new locality, Muroran, including the nematocyst armament of the hydroid and medusa, accords well with that of the originally described material from the type locality, Akkeshi. However, previously undescribed character states were observed not only in the hydroid and medusa of both sexes from Muroran but also in the hydroid and medusa 

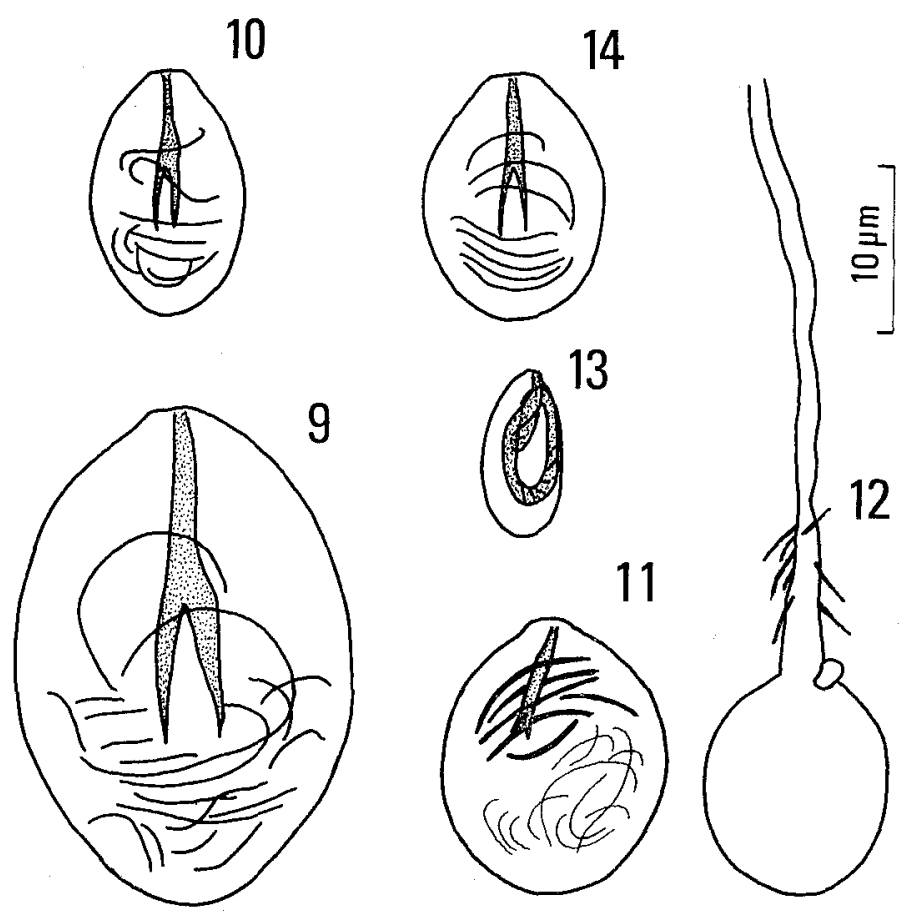

Figs. 9-14. Nematocysts of Sarsia japonica from Muroran, Hokkaido, Japan. 9, 10: Two types of stenoteles of hydroid. 11-14: Three kinds of nematocysts found on newly liberated medusae; microbasic mastigophores $(11,12)$ on exumbrella; desmoneme (13) on tentacle; and stenotele (14) on tentacle.

of males from Akkeshi in the following respects. The stalk of each medusa bud is not branched, but several (up to four) stalks arise very closely with one another, forming a cluster of medusa buds. We suspect that the branched stalk of medusa bud in the original description was misperceived. In a zooid from Muroran there are maximally four clusters of medusa buds, 14 medusa buds, and 24 capitate tentacles in four whorls. The mature or spent medusae sometimes possessed a conical or pointed apical knob. The manubrium sometimes reached the velar opening or slightly protruded from it. The umbrella attained $5.9 \mathrm{~mm}$ in height in a medusa from Muroran. Therefore the variation range of Sarsia japonica is wider than that noted in the original description by Nagao (1962).

Petersen (1990) recently pointed out that the morphology of the tentacular bulbs and the states of connection of the tentacular bulbs with both the tentacles and the radial canals of the mature medusa differ among the three corynid genera which were redefined by him. However, the present species exhibits character states that are inconsistent with Petersen's generic distinctions. The shape of the endodermal chamber of the tentacular bulb and the positioning of the distal ends of the radial canals of the present species are similar to those of Sarsia sensu Petersen (1990), while the position of tentacles is that of Dipurena sensu Petersen.

The present species resembles Sarsia producta, which is a distinct species in the 
"eximia"-group, as was pointed out by Brinckmann-Voss (1989). The known distinguishing characters of the hydroid and medusa in the two species are summarized in Table 3. The distributional pattern of the exumbrellar nematocysts is the most characteristic feature, as was originally pointed out by Nagao (1962). However, when the exumbrellar nematocysts decrease in number and the manubrium extends from the velar opening in $S$. japonica, as was encountered in the mature or spent medusa of the present specimens, it is difficult to distinguish $S$. japonica from $S$. producta.

The mature or spent medusa of $S$. japonica also resembles that of $S$. nipponica, which is also one of the "eximia"-group and occurs in southern Japan. Furthermore, these two species and $S$. producta constitute a monophyletic group in the cladogram

Table 3. Distinguishing characters of hydroids and medusae of Sarsia japonica and those of its closest congener, $S$. producta, compiled from the present study, Brinckmann-Voss (1989), Nagao (1962), Kramp (1961), Russell (1953), Rees (1938), and Mayer (1910).

\begin{tabular}{|c|c|c|}
\hline & Sarsia japonica (Nagao) & Sarsia producta (Wright) \\
\hline $\begin{array}{l}\text { Medusa } \\
\text { exumbrellar } \\
\text { nematocysts }\end{array}$ & in 8 adradial rows & irregularly scattered \\
\hline $\begin{array}{l}\text { well-developed } \\
\text { manubrium }\end{array}$ & $\begin{array}{l}\text { to level of umbrellar margin or } \\
\text { slightly protruding from um- } \\
\text { brellar aperture }\end{array}$ & $\begin{array}{l}\text { up to } 1 / 3 \text { beyond the umbrellar } \\
\text { margin }\end{array}$ \\
\hline $\begin{array}{l}\text { gonads on } \\
\text { manubrium }\end{array}$ & $\begin{array}{l}\text { on nearly whole region or on } \\
\text { the middle region }\end{array}$ & on nearly whole region \\
\hline apical knob & $\begin{array}{l}\text { conical with or without pointed } \\
\text { tip, or round in shape, or absent }\end{array}$ & $\begin{array}{l}\text { pointed as an apical projection } \\
\text { or conical in shape }\end{array}$ \\
\hline $\begin{array}{l}\text { width of } \\
\text { radial canal }\end{array}$ & wider than ring canal & unknown \\
\hline $\begin{array}{l}\text { maximum height } \\
\text { of umbrella }\end{array}$ & $5.9 \mathrm{~mm}$ & $10 \mathrm{~mm}$ \\
\hline $\begin{array}{l}\text { Hydroid } \\
\text { stalk of } \\
\text { medusa bud }\end{array}$ & $\begin{array}{l}\text { unbranched or with one or two } \\
\text { lateral branches* }\end{array}$ & unbranched \\
\hline $\begin{array}{l}\text { location of } \\
\text { medusa buds }\end{array}$ & $\begin{array}{l}\text { level of lowest whorl of capitate } \\
\text { tentacles or just below them }\end{array}$ & $\begin{array}{l}\text { level of lowest whorl of capitate } \\
\text { tentacles or lower than them }\end{array}$ \\
\hline $\begin{array}{l}\text { capitate } \\
\text { tentacles }\end{array}$ & $3-4$ whorls, up to 24 in number & $2-3$ whorls, up to 12 in number \\
\hline $\begin{array}{l}\text { ratio of max. } \\
\text { length of capitate } \\
\text { tentacle to max. } \\
\text { width of hydranth }\end{array}$ & $<2.2: 1$ & $<2.5: 1$ \\
\hline $\begin{array}{l}\text { filiform } \\
\text { tentacles }\end{array}$ & $\begin{array}{l}\text { up to } 5 \\
\text { in one whorl }\end{array}$ & $\begin{array}{l}\text { up to } 6 \\
\text { in one whorl }\end{array}$ \\
\hline hydrocaulus & rarely branched once or twice & branched irregularly \\
\hline
\end{tabular}

* As explained in text, the "branched" stalk seems to have been misperceived by the original author. 
produced by Petersen (1990). Sarsia japonica is distinguishable from S. nipponica in having adradial rows of exumbrellar nematocysts and longer tentacles bearing many nematocyst clusters in the medusa. Among the corynid medusae, S. nipponica only has short tentacles. Furthermore, in the hydroid of $S$. japonica, the capitate tentacles of at least the distal two or three whorls are all of the same length, while the tentacles in the most distal whorl are markedly longer than the others in S. nipponica (see Kubota 1991). Such a differential armament of capitate tentacles in the hydroid of $S$. nipponica is unique in the genus Coryne sensu Petersen (1990).

Substrata of hydroid and geographical distribution. The hydroid has so far been recorded in only two localities in Hokkaido, northern Japan, including the present record: shell surface of dead Fusitriton oregonense (Redfield, 1848), occasionally inhabited by a hermit-crab, Pagurus pectinatus (Stimpson, 1858), at a depth of 3-5 $\mathrm{m}$ at Akkeshi (the type locality) (Nagao 1962; present study); intertidal rocks covered by algae and bryozoans from Muroran, Hokkaido, Japan (present study); and tubes of Pseudopotamilla occelata Moore, 1905 from the intertidal region at Muroran, Hokkaido, Japan (present study). Bare rocks at Nakanose in Akkeshi Bay, ca. $5 \mathrm{~m}$ in depth, were utilized by three male colonies (present study). In nature, the mature medusa has so far been recorded only in Ucluelet Inlet, British Columbia, Canada (Arai \& Brinckmann-Voss 1980) and in Bodega Harbor, California (Rees 1975), the latter being considered as a doubtful record by Brinckmann-Voss (1989).

\section{Acknowledgments}

We wish to express our sincere gratitude to Prof. Eiji Harada, Prof. Mayumi Yamada and Dr. Mark J. Grygier for their critical reading of the manuscript. Heartfelt thanks are due to Messrs. Masahiro Moroi, Hiroshi Namikawa, and Tomio Sato for their kind help in collecting material.

\section{References}

Arai, N.M. \& A. Brinckmann-Voss. 1980. Hydromedusae of British Columbia and Puget Sound. Can. Bull. Fish. Aquat. Sci., 204: 1-192.

Brinckmann-Voss, A. 1989. Sarsia cliffordi n. sp. (Cnidaria, Hydrozoa, Anthomedusae) from British Columbia, with distribution records and evaluation of related species. Can. J. Zool., 67: 685-691.

Hirohito, His Majesty the Emperor Showa of Japan. 1988. The Hydroids of Sagami Bay. Biol. Lab. Imp. Household, Tokyo, 179 pp. +110 pp. (text in Japanese), 2 maps.

Kubota, S. 1988 . Taxonomic study on Hydrocoryne miurensis (Hydrozoa; Hydrocorynidae) in Japan. Publ. Seto Mar. Biol. Lab., 33(1/3): 1-18.

Kubota, S. 1991. Taxonomic notes on polyp and medusa of Sarsia nipponica Uchida (Hydrozoa: Corynidae) from the type locality in Japan. Publ. Seto Mar. Biol. Lab., 35(1/3): 17-23.

Kramp, P.L. 1961. Synopsis of the medusae of the wor!d. J. Mar. Biol. Ass. U.K., 40: 1-469.

Mayer, A.G. 1910. Medusae of the world. I. Hydromeduase. 230 pp., pls. 1-29, Carnegie Inst. Washington.

Nagao, Z. 1962. The polyp and medusa of the hydrozoan, Stauridiosarsia japonica n. sp., from Akkeshi, Hokkaido. Annot. zool. Japon., 35(3): 176-181.

Petersen, K.W. 1990. Evolution and taxonomy in capitate hydroids and medusae (Gnidaria: Hydrozoa). Zool. J. Linnean Soc., 100: 101-231.

Rees, J.T. 1975. Studies on Hydrozoa of the central Galifornia coast. Aspects of systematics and 
ecology. Ph. D. dissertation, University of California, Berkeley.

Rees, W.J. 1938. Observations on British and Norwegian hydroids and their medusae. J. Mar. Biol. Ass. U.K., 23: 1-42.

Russell, F.S. 1953. The medusae of the British Isles. 530 pp., pls. 1-35. Cambridge Univ. Press, London. 